\title{
Mechanochemical Synthesis, In vivo Anti-malarial and Safety Evaluation of Amodiaquine-zinc Complex
}

\author{
Rotimi Olusanya Arise ${ }^{1}$, Sunday-Nwaso Elizabeth ${ }^{1}, S$ Samuel Tobi Farohunbi ${ }^{1}$, \\ Mikhail Olugbemiro Nafiu ${ }^{1}$, Adedibu Clement Tella ${ }^{2}$ \\ ${ }^{1}$ Department of Biochemistry, University of Ilorin, Nigeria \\ ${ }^{2}$ Department of Chemistry, University of Ilorin, Nigeria
}

\section{SUMMARY}

So far, some prospective metal-based anti-malarial drugs have been developed. The mechanochemical synthesis and characterization of $\mathrm{Zn}$ (II) complex with amodiaquine and its anti-malarial efficacy on Plasmodium berghei-infected mice and safety evaluation were described in this study.

Solvent-free mechanochemical synthesis and characterization of $\mathrm{Zn}$ (II) complex with amodiaquine as well as its anti-malarial efficacy on NK-65 Plasmodium berghei-infected mice and safety were evaluated.

Derivatization of amodiaquine with zinc (II) ion enhanced the activity of the drug through significant ( $p<0.05)$ enhancement of parasitemia suppression in established malaria infection in comparison with the controls, while its capacity to clear malaria parasite was similar to that of chloroquine. A significant reduction in the liver, kidney and small intestinal activities of alkaline phosphatase, lactate dehydrogenase and alanine and aspartate aminotransferases was observed, while their levels increased significantly in the plasma. Levels of PCV, $\mathrm{Hb}, \mathrm{RBC}$ and lymphocytes were significantly reduced $(\mathrm{p}<0.05)$, and significant elevation $(\mathrm{p}<0.05)$ in WBC and neutrophil concentrations across all the treatment groups when compared with control was observed.

The result indicates that coordination of zinc (II) to amodiaquine by mechanical induction improved its anti-malarial activity, while the alterations in the investigated biochemical parameters suggest functional and structural toxicity. Thus, Zn (II) complex with amodiaquine may not be completely safe for prolonged and repeated use as an oral anti-malarial remedy. evaluation

Key words: antimalarial, amodiaquine-zinc, mechanochemical synthesis, in vivo and safety

Corresponding author:

Rotimi Arise

Email: ariserotimi@gmail.com 


\section{INTRODUCTION}

Malaria, a parasitic disease which occurs mainly in tropical zones of the world, has contributed greatly to health burden of the global population. According to the latest estimate, malaria affects more than 2 million people annually and causes about 627,000 deaths (1). In Africa, the majority of deaths occur among children, where estimate has it that the death of a child resulting from malaria occurs every minute (1). All year round, cases of transmission occur in the southern part of Nigeria; it is, however, more seasonal in the North (2). Plasmodium parasite causes malaria and it is transmitted to the human through the bites of infected Anopheles mosquito which bites mainly between dusk and dawn. Plasmodium falciparum, Plasmodium vivax, Plasmodium malariae and Plasmodium ovale are the four species of plasmodium that cause human malaria (3). $P$. falciparum most frequently causes the infection and is responsible for nearly all malaria-related deaths (3). However, $P$. berghei is a unicellular parasite that infects rodent and is employed as a model organism in the laboratory for the experimental study of human malaria (4).

The treatment of malaria with effective drugs remains a valuable method of reducing morbidity and mortality rate of the disease. Mostly used anti-malarial agents, such as chloroquine, amodaquine and 4-aminoquinoline derivatives, inhibit the formation of B-haematin (malaria pigment), which is lethal to the parasite (5).

Unfortunately, plasmodial parasites have developed resistance to most of these conventional drugs used in the treatment of malaria. Consequently, malaria resistance has led to an increase in the global cost of eradicating the disease, plus the financial implication of developing new drugs (6). The emergence and persistent problem of drug resistance, especially to $P$. falciparum, have directed the course of research towards the design of new and more potent drugs, natural or synthetic, with innovative approach as resurgence of interest in the old drugs (7).

Following the discovery of cisplatin (a platinumcontaining anti-cancer drug), and its subsequent clinical success in the treatment of cancer, transition metal-based anti-malarial drugs came into existence. In the late $20^{\text {th }}$ century, curiosity in complexes with increased therapeutic potential started to arouse interests. Several studies have been conducted on complexation of some common anti-malarial drugs with metals (7). Some potentially efficacious metal-derivatized anti-malarial drugs are now in use (8). Many of the synthesized metal-based anti-malarial drugs were found effective in the reduction of malaria parasite better than the ordinary anti-malarial drugs.

Previous works have shown that coordination with transition metal ions increases activities of some therapeutic agents (9). Developing appropriate, highly efficient and environmentally-friendly synthetic metallodrugs has become an emerging challenge. The global society is progressively aware of the environmental impact of human activities as a result of the need to produce cleaner and more energy-efficient technologies (11). It has also been said that "the best solvent is no solvent" (12). Solventless synthesis has several benefits over solution synthesis. It is induced at room temperature instead of the refluxing temperature of 100-300 ${ }^{\circ} \mathrm{C}$ utilized in the solution synthesis. This method reduces environmental contamination by abolishing and minimizing the use of organic solvents. Also, this method does not involve complex reaction and technique. The duration of synthesis is short (in the range of several minutes) compared to most solution-phase reactions (13). Therefore, in continuous search to find new antimalarial drugs that are effective against resistant strain of Plasmodium parasite, this paper present solvent-free mechanochemical synthesis of amodiaquine-zinc complex as well as its characterization and anti-malarial efficacy on $P$. berghei-infected mice and safety evaluations.

\section{MATERIALS AND METHODS}

\section{Source of reagents}

Chemicals and reagents were of analytical grades and were used without further purification. Reagent and solvents were purchased from Sigma Chemical Co, St. Louis, MO, USA. Alkaline phosphatase (ALP), alanine aminotransferase (ALT), aspartate aminotransferase (AST) and lactate dehydrogenase (LDH) assay kits are products of Randox Laboratories Limited, Antrim, United Kingdom.

FT-IR spectra of the ligand and the complexes were recorded in $\mathrm{KBr}$ pellets in the range of $4000-400 \mathrm{~cm}$ 1 on a SHIMADZU scientific model 500 FITR spectrophotometer with resolution $4(1 / \mathrm{cm})$. Electronic spectra were done on an Aquamate Spectrophotometer, Model V4.60. X-ray powder diffraction patterns were recorded on a Huber Imaging Plate Guinier Camera 670 with $\mathrm{CuK} \alpha 1$-radiation. Typical scanning times were 20 min over a $2 \theta$-range of $0-40^{\circ}$. AAS analysis was carried out on an Atomic Absorption Spectrophotometer Model 
6503 Jenway. Elemental analysis was performed on a Perkin-Elmer CHN Analyzer 2400 Series II.

\section{Source of mice and parasite}

Thirty (30) male albino mice (Mus musculus), average body weight $26.01 \pm 0.21 \mathrm{~g}$ were obtained from the Animal Breeding Unit of the Department of Biochemistry, University of Ilorin, Ilorin, Nigeria while the parasite $P$. berghei was obtained from the Institute of Advanced Medical Research and Training (IMRAT), University of Ibadan, Nigeria.

\section{Solid state synthesis of amodiaquine-zinc $\left(\mathrm{AMDH}^{+}\right)^{2+}\left(\mathrm{ZnCl}_{4}\right)^{2-}$ complex}

Amodiaquine ( $2 \mathrm{mmol}, 0.856 \mathrm{~g}$ ) and zinc chloride $\left(\mathrm{ZnCl}_{2} .2 \mathrm{H}_{2} \mathrm{O} ; 1 \mathrm{mmol}, 0.136 \mathrm{~g}\right)$ were weighed into a previously washed and dried mortar. Using mortar and pestle at room temperature, the reactants were ground continuously for $15 \mathrm{~min}$ to a fine paste. The progress of the reaction was monitored by thin layer chromatography (TLC) at an interval of $5 \mathrm{~min}$ of grinding. The grinding continued for 30 minutes overall until no traces of reactants were found. The white powder obtained was washed with methanol to remove unreacted starting materials and dried at room temperature. Fine white powder was obtained as product.

1a : Yield: 90.4 ; M. wt - 564.87 g/mol, M. pt $-264^{\circ} \mathrm{C}$; Anal. Calc. for $\mathrm{C}_{20} \mathrm{H}_{24} \mathrm{~N}_{3} \mathrm{Cl}_{5} \mathrm{OZn}$ : C: $42.49 ; \mathrm{H}: 4.25 ; \mathrm{N}$ : 7.44; Zn: 11.56. Found: C: 42.86; H: 4.20; N: 7.32, Zn:11.27. IR(KBR, $\left.\mathrm{cm}^{-1}\right)$ : 3292,3095, 2974, 2336,1612, 1591, 1581, 1508, 1435, 1366, 1263, 1257, 1190 , 1095, 1018, 920, 792, 584, 484, 418; UV-Vis(DMSO) $\lambda, \mathrm{nm}: 224,296$

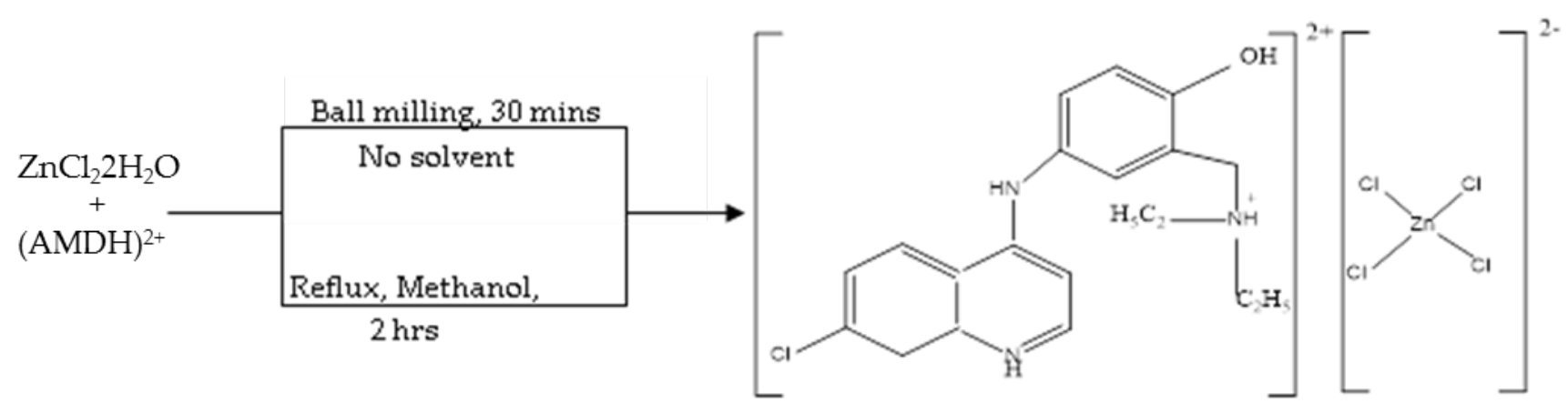

$(\mathrm{AMDH})^{2+}=$ amodiaquine cation

Scheme 1. Mechanochemical synthesis of tetrachlorometallate salts of amodiaquine

\section{Solvent-based synthesis of $(\mathrm{AMDH})^{2+}\left(\mathrm{ZnCl}_{4}\right)^{2-}$}

A solution of amodiaquine ( $2 \mathrm{mmol}, 0.856 \mathrm{~g}$ ) in methanol $(10 \mathrm{ml})$ was added to a solution of zinc chloride $\left(\mathrm{ZnCl}_{2} .2 \mathrm{H}_{2} \mathrm{O} ; 1 \mathrm{mmol}, 0.240 \mathrm{~g}\right)$ in methanol $(10$ $\mathrm{ml})$. The resulting solution was refluxed for $120 \mathrm{~min}$ at $70{ }^{\circ} \mathrm{C}$, filtered and allowed to evaporate for 2 days at room temperature, after which white crystalline powder was obtained as product.

$1 \mathrm{~b}$ : Yield: $78.4 \mathrm{M} . \mathrm{wt}=564.87 \mathrm{~g} / \mathrm{mol}, \mathrm{M} . \mathrm{pt}-261^{\circ} \mathrm{C}$, Anal. Calc. for $\mathrm{C}_{20} \mathrm{H}_{24} \mathrm{~N}_{3} \mathrm{Cl}_{5} \mathrm{OZn}$ : C:42.49; H: 4.25; N: 7.44; Zn: 11.56. Found: C:41.78; H: 4.14; N: 7.45, Zn: 11.30. $\operatorname{IR}\left(\mathrm{KBR}, \mathrm{cm}^{-1}\right): 3296,3097,2956,2335$, 1593, 1579, 1508, 1437, 1363, 1265, 1255, $1195,1095,1018,922,860.792$, 584, 480, 415; UV-Vis(DMSO) $\lambda$, nm: 218, 279

\section{Anti-malarial screening and safety evaluation of amodiaquine-zinc complex}

Mice for experiment were infected as described by Sanchez-Delgado et al. (14). Swiss mice were randomly distributed into 6 groups of 5 mice each, as follows;

Group 1 - Control;

Group 2 - Parasite-infected but untreated (IBNT);

Group 3 - Parasite-infected, chloroquine-treated (ITWC);

Group 4 - Parasite-infected and amodiaquine-treated (ITWA);

Group 5 - Parasite-infected and amodiaquine-Zn complex-treated (ITAZ);

Group 6 - Not infected but amodiaquine-Zn complextreated (NIAZ). 
The mice were inoculated intravenously with 0.2 $\mathrm{ml}$ of 1 x 106 parasite-infected red blood cells suspended in buffered physiological saline ( $\mathrm{pH}$ 7.4). Four days after infection, parasitemia levels of the mice were monitored everyday by counting parasites in blood smear fixed with $70 \%$ methanol and Giemsa stain. The slides were examined under the microscope at a magnification of $\times 100$. The level of parasitemia was thereafter determined by counting the number of infected erythrocytes / 1000 erythrocytes in tail blood smears stained with Giemsa.
$0.2 \mathrm{ml}$ of each drug solution (corresponding to $7.7 \mathrm{mg} / \mathrm{kg}$ body weight) was daily and orally administered to the mice in each group from day 0 to day 3 of infection.

Level of parasitemia was determined on day 4 . The control animals were administered physiological saline solution only. The results obtained were presented as the percentage of infected cells or inhibition of parasites and percentage chemosuppression of parasite multiplication by the drugs.

$$
\begin{gathered}
\% \text { Parasitemia }=\frac{\text { Total number of parasitized red blood cells counted } \times 100}{\text { Total number of red blood cells counted }} \\
\text { Parasitemia of test } \\
\% \text { Chemosuppression }=100-\left(\frac{(}{\text { Parasitemia of control }}\right)
\end{gathered}
$$

\section{Preparation of tissue and serum homogenate}

The experimental animals were sacrificed $24 \mathrm{~h}$ following the last day of drug administration by anaesthetizing with ether and blood samples were collected from the ocular orbit into heparinized bottles. They were then centrifuged and obtained from the plasma. The homogenates of the liver, kidney and small intestine were prepared in ice-cold $0.25 \mathrm{M}$ sucrose solution to give a final volume of five times the original tissue weight $(1.5 \mathrm{w} / \mathrm{v})$. The homogenates were kept in well labeled container and stored in the freezer before use.

\section{Determination of enzyme activities}

Alkaline phosphatase (ALP) activity was determined according to the method described by Wright et al. (15). Aspartate and alanine aminotransferases (ALT and AST) activities were assayed using the method described by Reitman and Frankel (16). Lactate dehydrogenase (LDH) activity was determined using the method described by Wroblewski and La Due (17).

\section{Determination of haematological indices}

Hematological parameters analyzed include $\mathrm{Hb}$, RBC, WBC, PVC, neutrophil and lymphocyte. The haematological parameters studied were determined using the automated haematology analyzer SYSMEX KX21 (SYSMEX Corporation, Japan).

\section{Statistical analysis}

Results were expressed as means of (5) five determinations \pm SEM. Data were statistically analyzed using one-way ANOVA, followed by Student's unpaired t-test. Differences were considered statistically significant at $\mathrm{p}<0.05$.

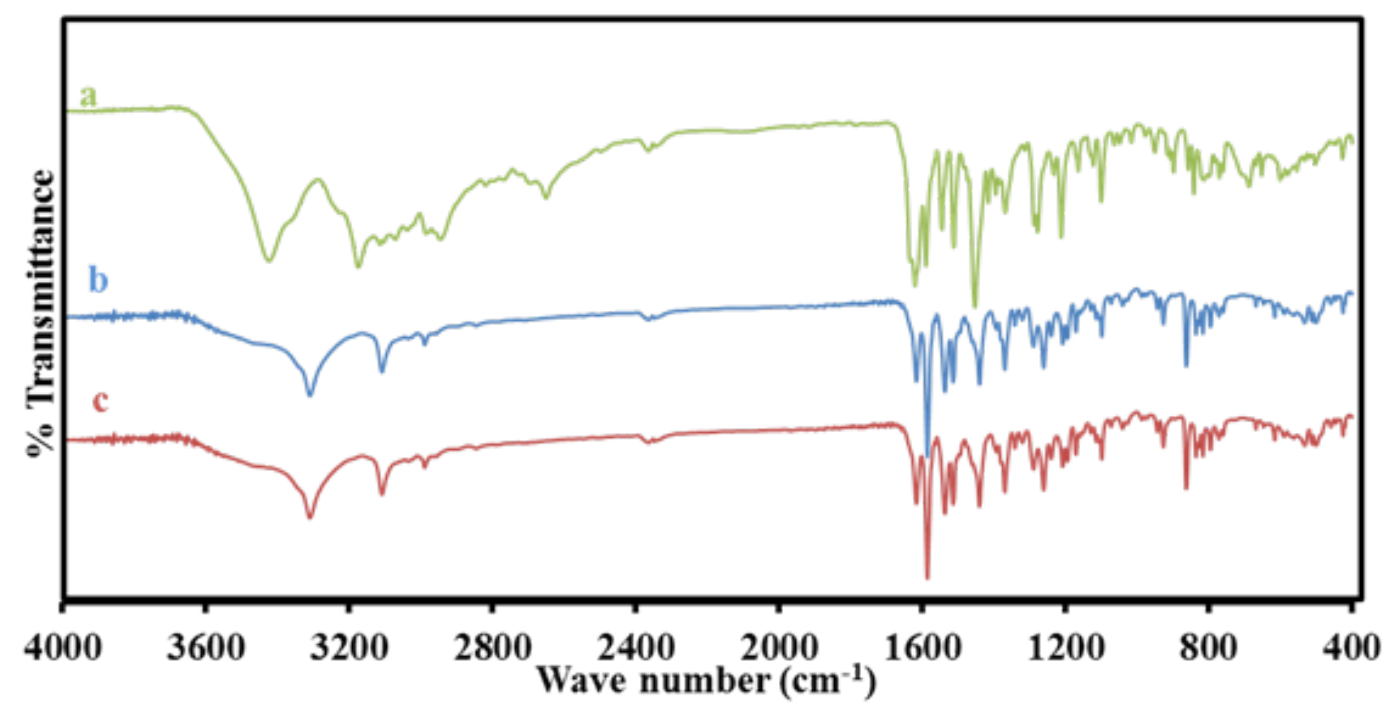

Figure 1: Comparison of FT-IR spectra of (a) Amodiaquine ligand (b) $[\mathrm{AMDH}]^{2+}\left[\mathrm{ZnCl}_{4}\right]^{2-}$ (Mechanochemically synthesized) (c) $[\mathrm{AMDH}]^{2+}\left[\mathrm{ZnCl}_{4}\right]^{2-}$ (solvent-based) 
Table 1: Selected FT-IR absorption band $\left(\mathrm{cm}^{-1}\right)$ for Amodiaquine $1 \mathrm{a}$ and $1 \mathrm{~b}$

\begin{tabular}{|c|c|c|c|c|c|}
\hline $\mathrm{S} / \mathrm{N}$ & Ligand/Complex & $v(\mathrm{OH})$ & $v_{s}(\mathrm{C}=\mathrm{N})$ & $v_{s}(\mathrm{C}-\mathrm{H})$ & $v(\mathrm{C}-\mathrm{Cl})$ \\
\hline 1. & Amodiaquine & 3408 & 1587 & $1587 \mathrm{~m}, 1618 \mathrm{~s}$ & $1452 b$ \\
\hline 2. & $\begin{array}{l}{[\mathrm{AMDH}]^{2+}\left[\mathrm{ZnCl}_{4}\right]^{2-}} \\
\text { Mechanochemical 1a }\end{array}$ & 3292 & 1594 & $\begin{array}{l}1587 \mathrm{~s} \\
1616 \mathrm{~m}\end{array}$ & $\begin{array}{l}1400 \mathrm{~b} \\
1431 \mathrm{~b}, \\
1456 \mathrm{w}\end{array}$ \\
\hline 3. & $\begin{array}{l}{[\mathrm{AMDH}]^{2+}\left[\mathrm{ZnCl}_{4}\right]^{2-}} \\
\text { Solvent-based } \mathbf{1 b}\end{array}$ & 3296 & 1593 & $\begin{array}{l}1585 \mathrm{~s}, \\
1616 \mathrm{~m}\end{array}$ & $\begin{array}{l}1400 \mathrm{~b} \\
1431 \mathrm{~b} \\
1456 \mathrm{w}\end{array}$ \\
\hline
\end{tabular}

\section{RESULTS}

Compounds $1 \mathrm{a}$ and $1 \mathrm{~b}$ were obtained as white powder via mechanochemical grinding and refluxing in methanol. The mechanochemical method was carried out by manual grinding of Amodiaquine and Zinc chloride dihydrate using mortar and pestle. The reaction was done within 30 minutes at room temperature as compared to solvent-based reaction $(120 \mathrm{~min}$ in methanol at $70{ }^{\circ}$ ) and 2 days for product to form. The elemental analysis and spectroscopic data (IR, UV-VIS spectra and PXRD) of the compounds prepared via the two different methods are almost identical. The IR spectra of the compounds are shown in Figure 1 and selected bands are given in Table 1 . Comparison of the spectra of Amodiaquine with $1 \mathrm{a}$ and $1 \mathrm{~b}$ showed that the band due to $v(\mathrm{OH})$ at $3408 \mathrm{~cm}^{-1}$ in the free amodiaquine ligand shifted to $3292 \mathrm{~cm}^{-1}$ in $1 \mathrm{a}$ and $3296 \mathrm{~cm}^{-1}$ in $1 \mathrm{~b}$ as a result of hydrogen bonding between this group and chlorine atoms and also of mechanical stirring and complex formation - the band at $1587 \mathrm{~cm}^{-1}$ assigned to $v(\mathrm{C}=\mathrm{N})$ experienced little shift to 1591 in 1a and 1593 $\mathrm{cm}^{-1}$ in $1 \mathrm{~b}$; however, this is not significant enough to indicate coordination. The spectroscopic data combined with elemental analysis results support the structures proposed for $1 \mathrm{a}$ and $1 \mathrm{~b}$ (Scheme 1$)$.

\section{IR studies}

The absorption band in range 2931- $2974 \mathrm{~cm}^{-1}$ due to $v(\mathrm{C}-\mathrm{H})$ is attributed to stretching vibration of the methylene group in quinuclidine molecule for the compounds $1 \mathrm{a}$ and $1 \mathrm{~b}$.

The $v(\mathrm{C}-\mathrm{Cl})$ in quinolone group of the Amodiaquine observed at $1095 \mathrm{~cm}^{-1}$ did not change significantly in $1 \mathrm{a}$ and $1 \mathrm{~b}$, indicating that chlorine atom is not involved in the coordination to the metal ion.

Results from FTIR data for these compounds revealed that there is no direct metal-drug coordination. In addition, the FT-IR spectra of the complexes synthesized via the two methods are identical, but different from the free ligand (amodiaquine), suggesting that both methods produced similar products.

\section{Electronic spectra}

UV/VIS spectra data of Amodiaquine $1 \mathrm{a}$ and $1 \mathrm{~b}$ are given in Table 2. It can be seen from the table that selected UV/VIS spectrum of the Amodiaquine presents two absorption bands at $\lambda \max =210 \mathrm{~nm}$ and $256 \mathrm{~nm}$ assigned to $\pi \rightarrow \pi^{*}$ and $\pi \rightarrow \mathrm{n}^{*}$. The same band are obtained around the same wavelengths, in 1a (224 nm and $296 \mathrm{~nm}$ in $1 \mathrm{~b}$ (218 nm and $278 \mathrm{~nm})$. As expected, $\mathrm{Zn}$ (II) compounds do not have additional bands in the visible region. Batochromic shifts of the first and second bands points to complex formation. It has $\mathrm{d} 10$ configuration as there is no $\mathrm{d}-\mathrm{d}$ transition.

\section{X-ray powder diffraction analysis}

Figure 2 shows that the powder x-ray diffraction patterns (PXRD) of the mechanochemical product (solidstate compound) was different from the PXRD of the reactants (amodiaquine ligand and $\mathrm{Zn}(\mathrm{II})$ ion. New peaks corresponding to the mechanochemical product were observed at $2 \theta=16.30^{\circ}, 17.60^{\circ}, 22.60^{\circ}$ and $22.25^{\circ}$ which are absent in the ligand indicating formation of new phase. Quantitative estimation of the $2 \theta$ PXRD patterns of the product $1 \mathrm{a}$ and $1 \mathrm{~b}$ was carried out. The major peaks in PXRD pattern of 1 a were observed at $2 \theta=$ 6.10, 7.50, 11.00, 13.10, 15.30, 17.60, 19.65, 21.35, 22.60, $25.25,29.56,32.40$, while that of $1 \mathrm{~b}$ were observed at $2 \theta=$ $6.02,7.53,11.20,12.95,15.20,17.50,19.60,21.30,22.50$, $25.10,29.60$ and 32.40 . The closeness of the $2 \theta$ shown in Figure 2 indicates that the two compounds mechanochemical product and solvent-based (products) are identical.

\section{In-vivo anti-malarial and safety evaluation}

Figure 3 represents the percentage of parasiteamia in infected mice treated with chloroquine, amodia- 
quine and amodiaquine-Zn complex. There was no significant increase $(p>0.05)$ in parasitemia in the mice that were infected and not treated when compared to parasite level on day 0 . The parasite level in mice treated with chloroquine and amodiaquine-Zn complex reduced below $5 \%$ by the $5^{\text {th }}$ day, while those treated with amodiaquine decreased by $6 \%$. The percentage reduction of parasitemia in groups treated with chloroquine and amodiaquine-Zn complex showed no significant difference ( $p>0.05)$. However, all the animals in all the test groups survived beyond the experimental period.

Table 2: UV-Visible Spectra of Amodiaquine 1a and 1b

\begin{tabular}{c|c|c}
\hline \hline Ligand/ compound & Wavelength(nm) & Assignments \\
\hline Amodiaquine & 210 & $\pi \rightarrow \pi^{*}$ \\
& 256 & $\mathrm{n} \rightarrow \pi^{*}$ \\
\hline 1a & 224 & $\pi \rightarrow \pi^{*}$ \\
& 296 & $\mathrm{n} \rightarrow \pi^{*}$ \\
\hline 1b & 218 & $\pi \rightarrow \pi^{*}$ \\
& 278 & $\mathrm{n} \rightarrow \pi^{*}$ \\
\hline \hline
\end{tabular}

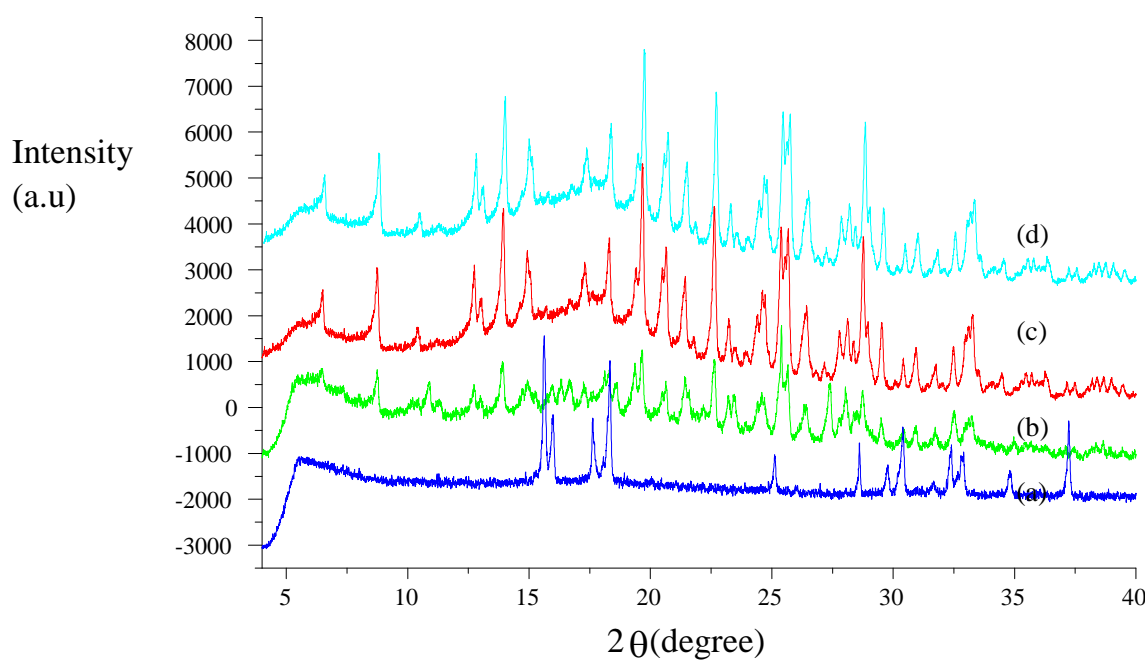

Figure 2: Comparison of XRPD patterns of reactants - (a) $\mathrm{ZnCl}_{2}$ (b) Amodiaquine ligand

(c) $[\mathrm{AMDH}]^{2+}\left[\mathrm{ZnCl}_{4}\right]^{2-}\left(\right.$ Solvent-based) (d) $[\mathrm{AMDH}]^{2+}\left[\mathrm{ZnCl}_{4}\right]^{2-}$ (Solvent-free)

Table 3: Percentage of chemosuppression of parasite multiplication by the drugs

\begin{tabular}{l|c|c|c}
\hline \hline Treatments & Day 5 & Day 6 & Day 7 \\
\hline Chloroquine & 35.28 & 65.00 & 92.85 \\
Amodiaquine & 29.28 & 62.57 & 85.42 \\
Amodiaquine-Zn & 32.85 & 63.57 & 90.85 \\
\hline \hline
\end{tabular}

Table 3 represents the percentage of chemosuppression of parasite multiplication following administration of amodiaquine and amodiaquine- $\mathrm{Zn}$ complex. The percentage of chemosuppression of mice treated with amodiaquine- $\mathrm{Zn}$ complex is relatively similar to that of the chloroquine group which increased significantly $(\mathrm{p}<0.05)$. Amodiaquine attained $85.42 \%$ by day 7, while amodiaquine-Zn complex attained $90.85 \%$. 
Tables 4-7 show the effect of the administration of amodiaquine, amodiaquine-zinc complex and chloroquine to mice (infected and uninfected) for four days on the activities of ALP, ALT, AST and LDH, respectively. There was a significant reduction $(\mathrm{p}<0.05)$ in the activity of ALP, when compared with the control in liver, kidney and small intestine of the treatment groups. The reduction was well pronounced in the group treated with amodiaquine-zinc complex and accompanied by a significant increase $(p<0.05)$ in the enzyme activity in the plasma of all the treated groups (Table 4). The activity of ALT in all the studied organs of the treatment groups decreased, with a concomitant increase in the plasma enzyme activity (Table 5). The administration of amodiaquine-Zinc complex caused a significant decrease $(p<0.05)$ in the level of AST of the studied organs in both infected and non-infected animals, with a concurrent rise in the plasma AST activity. Similar pattern was observed in the other treatment groups that received chloroquine and amodiaquine, but this is less pronounced when compared to that of amodiaquinezinc complex (Table 6). Figure 3 represents the percentage of parasitaemia in infected mice administered amodiaquine and amodiaquine-zinc complex. LDH activity of the liver, kidney and small intestine (except the kidney of the non-infected group) decreased significantly ( $p<0.05$ ), while there was a corresponding increase in the activity of the enzyme in the plasma when compared with the controls (Table 7). Table 8 presents the effect of the administration of amodiaquine and amodiaquine- $\mathrm{Zn}$ complex on heamatological indices of infected and uninfected mice. There was a significant decrease $(\mathrm{p}<0.05)$ in the levels of $\mathrm{PCV}, \mathrm{Hb}$, $\mathrm{RBC}$ and lymphocytes and a significant increase $(\mathrm{p}<$ 0.05) in WBC and neutrophil concentrations across all the treatment groups when compared with control.

Table 4: Effect of amodiaquine and amodiaquine-Zn complex on the specific activity of alkaline phosphatase (ALP) in selected tissues and plasma of mice

\begin{tabular}{lcccccc}
\hline \hline & Control & IBNT & ITWC & ITWA & ITAZ & NIAZ \\
\hline Liver & $2.58 \pm 0.21^{\mathrm{a}}$ & $1.31 \pm 0.09^{\mathrm{b}}$ & $1.12 \pm 0.08^{\mathrm{c}}$ & $1.17 \pm 0.99^{\mathrm{c}}$ & $1.09 \pm 0.05^{\mathrm{c}}$ & $1.11 \pm 0.07^{\mathrm{c}}$ \\
Kidney & $3.30 \pm 0.17^{\mathrm{a}}$ & $3.09 \pm 0.17^{\mathrm{a}}$ & $1.98 \pm 0.09^{\mathrm{b}}$ & $2.00 \pm 0.19^{\mathrm{b}}$ & $1.92 \pm 0.08^{\mathrm{b}}$ & $1.99 \pm 0.05^{\mathrm{b}}$ \\
Small Intestine & $4.31 \pm 0.32^{\mathrm{a}}$ & $3.41 \pm 0.22^{\mathrm{a}}$ & $2.19 \pm 0.10^{\mathrm{b}}$ & $2.37 \pm 0.21^{\mathrm{b}}$ & $1.99 \pm 0.06^{\mathrm{b}}$ & $2.01 \pm 0.09^{\mathrm{b}}$ \\
Plasma & $1.75 \pm 0.07^{\mathrm{a}}$ & $2.50 \pm 0.08^{\mathrm{b}}$ & $3.44 \pm 0.11^{\mathrm{c}}$ & $3.33 \pm 0.10^{\mathrm{c}}$ & $4.31 \pm 0.21^{\mathrm{d}}$ & $3.99 \pm 0.13^{\mathrm{c}, \mathrm{d}}$ \\
\hline \hline
\end{tabular}

Values are mean of 5 determinations \pm SEM. Rows with different superscripts are significantly $(p<0.05)$ different. Key:

IBNT -Infected but not treated

ITWC-Infected and treated with chloroquine

ITWA-Infected and treated with amodiaquine

ITAZ-Infected and treated with amodiaquine-Zn

NIAZ-Not infected but treated with amodiaquine-Zn

Table 5: Effect of amodiaquine and amodiaquine-Zn complex on the activity of alanine aminotransferase (ALT) in selected tissue and plasma of mice

\begin{tabular}{lcccccc}
\hline \hline & Control & IBNT & ITWC & ITWA & ITAZ & NIAZ \\
\hline Liver & $15.50 \pm 1.12^{\mathrm{a}}$ & $9.75 \pm 0.53^{\mathrm{b}}$ & $7.50 \pm 0.17^{\mathrm{c}}$ & $6.25 \pm 0.24^{\mathrm{d}}$ & $7.75 \pm 0.16^{\mathrm{c}, \mathrm{e}}$ & $7.80 \pm 0.25^{\mathrm{e}}$ \\
Kidney & $1.63 \pm 0.02^{\mathrm{a}}$ & $0.93 \pm 0.06^{\mathrm{b}}$ & $0.60 \pm 0.02^{\mathrm{c}}$ & $0.32 \pm 0.01^{\mathrm{d}}$ & $0.37 \pm 0.01^{\mathrm{d}}$ & $0.32 \pm 0.01^{\mathrm{d}}$ \\
Small Intestine & $1.87 \pm 0.13^{\mathrm{a}}$ & $0.94 \pm 0.04^{\mathrm{b}}$ & $0.64 \pm 0.02^{\mathrm{c}}$ & $0.32 \pm 0.02^{\mathrm{d}}$ & $0.19 \pm 0.01^{\mathrm{e}}$ & $0.13 \pm 0.011^{\mathrm{e}}$ \\
Plasma & $1.83 \pm 0.12^{\mathrm{a}}$ & $2.67 \pm 0.14^{\mathrm{b}}$ & $2.64 \pm 0.11^{\mathrm{b}}$ & $3.52 \pm 0.10^{\mathrm{c}}$ & $3.60 \pm 0.14^{\mathrm{c}}$ & $4.17 \pm 0.23^{\mathrm{d}}$ \\
\hline \hline
\end{tabular}

Values are mean of 5 determinations \pm SEM. Rows with different superscripts are significantly $(p<0.05)$ different. Key:

IBNT -Infected but not treated

ITWC-Infected and treated with chloroquine

ITWA-Infected and treated with amodiaquine

ITAZ-Infected and treated with amodiaquine- $Z n$

NIAZ-Not infected but treated with amodiaquine-Zn 
Table 6: Effect of amodiaquine and amodiaquine-Zn complex on the activity of aspartate aminotransferase (AST) in selected tissues and plasma of mice

\begin{tabular}{|c|c|c|c|c|c|c|}
\hline & Control & IBNT & ITWC & ITWA & ITAZ & NIAZ \\
\hline Liver & $5.23 \pm 0.14^{\mathrm{a}}$ & $3.89 \pm 0.16^{b}$ & $2.50 \pm 0.13^{c}$ & $2.75 \pm 0.15^{c}$ & $2.01 \pm 0.09^{d}$ & $2.11 \pm 0.09^{d}$ \\
\hline Kidney & $1.86 \pm 0.04^{\mathrm{a}}$ & $1.07 \pm 0.02^{\mathrm{b}}$ & $0.63 \pm 0.04^{\mathrm{C}}$ & $0.56 \pm 0.02^{\mathrm{c}}$ & $0.23 \pm 0.01^{\mathrm{d}}$ & $0.23 \pm 0.01^{\mathrm{d}}$ \\
\hline Small Intestine & $0.83 \pm 0.01^{\mathrm{a}}$ & $0.46 \pm 0.02^{b}$ & $0.14 \pm 0.01^{\mathrm{c}}$ & $0.16 \pm 0.01^{\mathrm{c}}$ & $0.12 \pm 0.01^{\mathrm{c}}$ & $0.13 \pm 0.01^{c}$ \\
\hline Plasma & $1.41 \pm 0.10^{\mathrm{a}}$ & $2.05 \pm 0.08^{b}$ & $2.16 \pm 0.04^{\mathrm{b}}$ & $2.54 \pm 0.13^{c}$ & $2.57 \pm 0.15^{\mathrm{c}}$ & $2.60 \pm 0.13^{c}$ \\
\hline
\end{tabular}

Values are mean of 5 determinations \pm SEM. Rows with different superscripts are significantly $(p<0.05)$ different. Key:

IBNT -Infected but not treated

ITWC-Infected and treated with chloroquine

ITWA-Infected and treated with amodiaquine

ITAZ-Infected and treated with amodiaquine-Zn

NIAZ-Not infected but treated with amodiaquine-Zn

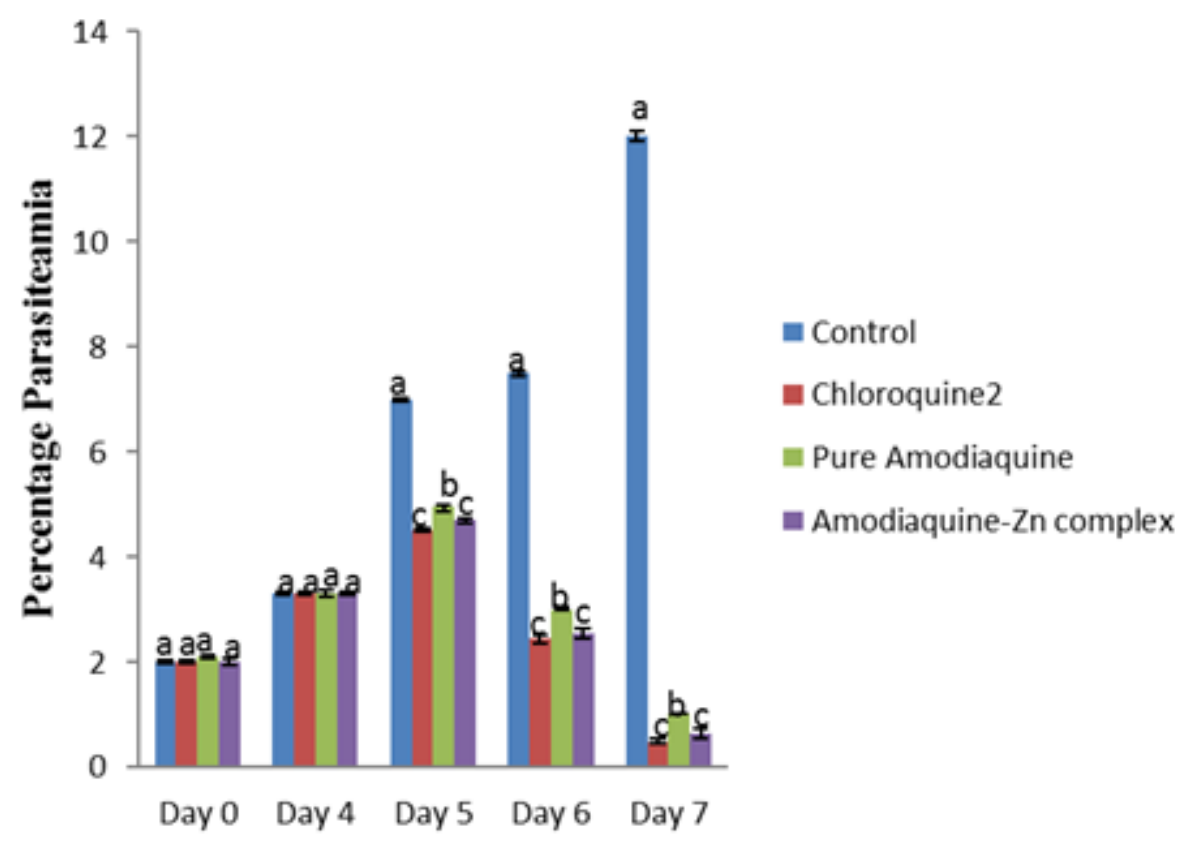

Values are means of 5 determinations \pm SEM and Bars with different superscripts are significantly different at $(p<0.05)$.

Figure 3: Percentage of parasitaemia of infected mice administered amodiaquine and amodiaquine-Zn complex 
Table 7: Effect of amodiaquine and amodiaquine-Zn complex on the activity of lactate dehydrogenase (LDH) in selected tissues and plasma of mice

\begin{tabular}{lcccccc}
\hline \hline & Control & IBNT & ITWC & ITWA & ITAZ & NIAZ \\
\hline Liver & $6.84 \pm 0.52^{\mathrm{a}}$ & $4.29 \pm 0.29^{\mathrm{b}}$ & $3.83 \pm 0.23^{\mathrm{c}}$ & $3.24 \pm 0.27^{\mathrm{c}}$ & $3.86 \pm 0.18^{\mathrm{c}}$ & $3.94 \pm 0.16^{\mathrm{c}}$ \\
Kidney & $9.42 \pm 0.43^{\mathrm{a}}$ & $6.89 \pm 0.12^{\mathrm{b}}$ & $3.57 \pm 0.29^{\mathrm{c}}$ & $3.87 \pm 0.13^{\mathrm{c}}$ & $6.16 \pm 0.46^{\mathrm{d}}$ & $10.15 \pm 0.71^{\mathrm{e}}$ \\
Small Intestine & $4.45 \pm 0.19^{\mathrm{a}}$ & $1.83 \pm 0.06^{\mathrm{b}}$ & $1.54 \pm 0.03^{\mathrm{b}}$ & $1.82 \pm 0.01^{\mathrm{b}}$ & $1.65 \pm 0.02^{\mathrm{b}}$ & $1.55 \pm 0.04^{\mathrm{b}}$ \\
Plasma LDH & $1.19 \pm 1.02^{\mathrm{a}}$ & $0.61 \pm 0.1^{\mathrm{b}}$ & $042 \pm 0.01^{\mathrm{c}}$ & $0.39 \pm 0.01^{\mathrm{c}}$ & $0.28 \pm 0.01^{\mathrm{d}}$ & $0.22 \pm 0.01^{\mathrm{d}}$ \\
\hline \hline
\end{tabular}

Values are mean of 5 determinations \pm SEM. Rows with different superscripts are significantly $(p<0.05)$ different. Key:

IBNT -Infected but not treated

ITWC-Infected and treated with chloroquine

ITWA-Infected and treated with amodiaquine

ITAZ-Infected and treated with amodiaquine-Zn

NIAZ-Not infected but treated with amodiaquine-Zn

Table 8: Effect of amodiaquine and amodiaquine-Zn complex on mouse haematological indices

\begin{tabular}{|c|c|c|c|c|c|c|}
\hline Parameters & Control & IBNT & ITWC & ITWA & ITAZ & NIAZ \\
\hline PCV (\%) & $40.25 \pm 1.88^{\mathrm{a}}$ & $34.50 \pm 1.55^{b}$ & $30.11 \pm 1.49^{c}$ & $30.25 \pm 1.75^{c}$ & $31.33 \pm 2.33^{c}$ & $32.75 \pm 1.25^{\mathrm{c}}$ \\
\hline Hb (g/dl) & $13.27 \pm 056^{\mathrm{a}}$ & $11.15 \pm 0.34^{\mathrm{b}}$ & $10.79 \pm 0.62^{b}$ & $11.50 \pm 0.45^{\mathrm{b}}$ & $10.40 \pm 0.90^{\mathrm{b}}$ & $11.17+0.28^{\mathrm{b}}$ \\
\hline $\operatorname{RBC}\left(\times 10^{12} / L\right)$ & $4.66 \pm 0.27^{\mathrm{a}}$ & $2.28 \pm 0.08^{\mathrm{b}}$ & $2.20 \pm 0.02^{\mathrm{b}}$ & $2.15 \pm 0.02^{\mathrm{b}}$ & $2.06 \pm 0.07^{\mathrm{b}}$ & $2.26 \pm 0.06^{\mathrm{b}}$ \\
\hline $\mathrm{WBC}\left(\times 10^{9} / \mathrm{L}\right)$ & $3.67 \pm 0.50^{\mathrm{a}}$ & $5.47 \pm 0.22^{\mathrm{b}}$ & $5.50 \pm 0.21^{\mathrm{b}}$ & $5.37 \pm 0.14^{\mathrm{b}, \mathrm{c}}$ & $6.30 \pm 0.75^{c}$ & $6.82 \pm 0.77^{\mathrm{C}}$ \\
\hline Neutrophil(\%) & $22.00 \pm 1.68^{\mathrm{a}}$ & $32.75 \pm 3.00^{\mathrm{a}}$ & $43.17 \pm 2.34^{b}$ & $44.75 \pm 4.69^{b}$ & $38.66 \pm 5.17^{b}$ & $43.75+4.60^{\mathrm{b}}$ \\
\hline Lymphocytes(\%) & $78.00 \pm 1.68^{\mathrm{a}}$ & $67.25 \pm 3.01^{\mathrm{b}}$ & $56.11 \pm 3.84^{\mathrm{b}}$ & $55.25 \pm 4.69^{\mathrm{b}}$ & $60.33 \pm 9.17^{\mathrm{b}}$ & $56.25+4.60^{\mathrm{b}}$ \\
\hline
\end{tabular}
Key:

Values are mean of 5 determinations \pm SEM. Rows with different superscripts are significantly $(p<0.05)$ different.

IBNT -Infected but not treated

ITWC-Infected and treated with chloroquine

ITWA-Infected and treated with amodiaquine

ITAZ-Infected and treated with amodiaquine-Zn

NIAZ-Not infected but treated with amodiaquine-Zn

\section{DISCUSSION}

Solvent-free reactions have gained increasing interest in recent years. Due to the problem of environmental pollution linked with solvent disposal and shrinking energy resources, there is a need to develop benign synthetic reactions which are simple and exhibit high atom economy. Synthesis from solution introduces additional costs related to solvent and its environmental impact and is also subject to limitation. As a society we are increasingly aware of the environmental impact of human activity and as a result of the need to develop cleaner and more energy-efficient technologies (18).
The outburst of malaria and drug-resistant strain of plasmodium have made malaria a leading killer disease in the world. The challenge of malaria-drug resistant led researchers in the direction of metal-based anti-malarial drugs. Many metal-complexes antimalarial drugs have been reported to possess antimalarial activity better than their parent compounds (7). In this study, zinc(II) complex with amodiaquine $\left(\mathrm{AMDH}^{+}\right)^{2+}\left(\mathrm{ZnCl}_{4}\right)^{2-}$ was synthesized via two methods: mechanochemical and solvent-based methods. The mechanochemical method involves safe and environmentally friendly synthetic reactions which are simple and exhibit high atom economy. This is needful as synthesis from solution introduces additional costs 
related to solvent and its environmental impact as well as its limitation (19).

The spectroscopic spectra of the complexes synthesized via two methods suggest that both methods produced similar products. Moreover, comparing the XRPD patterns of the reactant and the product further proved that mechanochemically synthesized and solvent-based $\left(\mathrm{AMDH}^{+}\right)^{2+}\left(\mathrm{ZnCl}_{4}\right)^{2-}$ are identical.

The reduction in percentage of parasitaemia, as well as the increase in percentage of chemosuppression of parasite when compared with the control, was more pronounced in mice treated with chloroquine and $\mathrm{Zn}$ (II) complex with amodiaquine) $\left(\mathrm{AMDH}^{+}\right)^{2+}\left(\mathrm{ZnCl}_{4}\right)^{2-}$ complex. This suggests that amodiaquine-zinc complex exhibits a stronger anti-malarial effect compared to its parent compound. The observed effects may be attributed to the fact that $\left(\mathrm{AMDH}^{+}\right)^{2+}\left(\mathrm{ZnCl}_{4}\right)^{2-}$ complex was more permeative into parasitized erythrocytes than its amodiaquine ligand. This is similar to what was reported by Arise et al. (2) on the study of lumefantrine complexed with copper. $\left(\mathrm{AMDH}^{+}\right)^{2+}\left(\mathrm{ZnCl}_{4}\right)^{2-}$ may have exchanged its bound zinc for ferric ions making the iron to be unavailable for vital parasite functions, thus suggesting $\left(\mathrm{AMDH}^{+}\right)^{2+}\left(\mathrm{ZnCl}_{4}\right)^{2-}$ may have a better therapeutic activity against amodiaquine (20-21).

The determination of the activities of various enzymes in tissues and body fluids plays a vital role in disease investigation and diagnosis (22). Measurement of enzyme activities can also be used to indicate tissue cellular damage caused by a chemical compound long before histological changes (23). Alkaline phosphatase is a marker enzyme for the plasma membrane and endoplasmic reticulum (24). It is usually used to assess the integrity of the plasma membrane (25). Results from this study suggest that the integrity of membrane systems of the rat tissues have been compromised by the administration of the drugs in all test groups since they exerted significant decrease on the activity of the enzyme. This is in agreement with recent studies that have reported that some antimalarial agents as well as their metal-complexed forms such as chloroquine (26), amodiaquine (27) and lumefantrine-copper complex (2) are capable of causing damage to the liver.
The significant reduction of lactate dehydrogenase (LDH), an enzyme associated with the cytosol (28), in the studied tissues, and its concurrent increase in the plasma, also suggest damage to plasma membrane by the drugs leading to excessive leakage of cytosolic materials including LDH into extracellular fluids (29).

The activity of alanine aminotransferase (ALT) in the blood increases when cells are damaged or dead (30). Increase in the activities of serum ALT and AST as observed in this study may be due to loss from some tissue into extracellular fluids because of the change in disruption of plasma membrane as stated earlier. High serum levels of AST and ALT have been used as markers for some forms of liver disorders. The significant fall in the levels in the liver, kidney and small intestine of ALT and AST activities in all the treatment groups is suggestive of damage to the plasma membrane of these tissues at the cellular level, leading to increased efflux of these enzymes into the extracellular fluid (29). While the decrease in the RBC and PCV observed in groups of mice infected and treated might be due to the decrease in the rate of production of erythrocytes, it may also suggest that that the drugs lacked erythropoeitin potential (30). The increase in WBC and neutrophil might be an indication that there was a challenge on the immune system.

\section{CONCLUSION}

In conclusion, mechanochemical synthesis of amodiaquine-zinc represents an ideal method of synthesizing a derivatized amodiaquine-zinc with no environmental pollution on the order of several minutes when compared to the solvent-based that leads to environmental pollution and takes a longer period of time. Coordination of zinc to amodiaquine by mechanical induction enhanced its antimalarial activity, while the alterations in the investigated biochemical parameters suggest selective, functional and structural toxicity. Thus, prolonged use of amodiaquine-zinc may not be completely safe for oral treatment. 


\section{References}

1. WHO: World Malaria Report 2015. Geneva: World Health Organization; 2015.

2. Arise $\mathrm{RO}$, Tella $\mathrm{AC}$, Iyiola $\mathrm{OA}$ et al. Solventless Synthesis, Antimalarial and Toxicity Evaluation of Lumefantrine-Copper Complex in Swiss Mice. Not Sci Biol, 2016; 8: 292-300.

3. Bertram G, Susan B, Anthony J. Basic and Clinical Pharmacology, 11th ed, Chapter 52, Antiprotozoal Drugs. The McGraw-Hill Companies, Inc. pp 10501063, 2009.

4. Combes V, de Souza JB, Renia L et al. Cerebral malaria: which parasite? Which model? Drug Disc Today: Dis Model. 2005; 2:141-7. https://doi.org/10.1016/j.ddmod.2005.05.015

5. Pratt Bawa S, Kumar S, Drabu S, Kumar R. Structural modifications of quinoline-based anti-malarial agents: Recent developments. J Pharm Bioallied Sci. 2010; 2:64-71.

https://doi.org/10.4103/0975-7406.67002

6. Phillips M, Phillips-Howard PA. Economic implications of resistance to anti-malarial drugs. Pharmacoeconomics. 1996; 10:225-38, https://doi.org/10.2165/00019053-199610030-00004

7. Adedeji JF, Olayinka ET, Adebayo MA, Babatunde O. Anti-malarial mixed metal complexes: Synthesis, physicochemical and biological activities. Int J Phys Sci. 2009; 4:529-34.

8. Sekhon BS, Bimal N. Transition metal-based antimalarial. J Pharm Educ Res. 20112; 3:52-63.

9. Ogunniran KA, Tella AC, Alensela M, Yakubu MT. Synthesis, physical properties. Antimicrobial potentials of some antibiotics complexes with transitional metals and their effect on alkaline phosphatise activities of selected rat tissues. Afr J Biotechnol. 2007; 6; 1202-8.

10. Obaleye JA, Caira MR, Tella AC. Synthesis and crystal structure of a Polymeric Zinc (II) complex containing antimalarial Quinine as ligand. J Chem Crystallogr. 2007; 37; 707-12.

\section{https://doi.org/10.1007/s10870-007-9236-3}

11. Cave GVW, Raston CL, Scott L. Recent advances in solventless organic reactions: towards benign synthesis with remarkable versatility. Chem Comm (Camb). 2001; 2159-69.

12. Huff JS, Sheldon RA. Green solvents for sustainable organic synthesis: State of the art. Green Chem. 2005; $7: 267$.

https://doi.org/10.1039/b418069k

13. Ye XR, Darario C, Wang C et al. Room Temperature Solvent-Free Synthesis of Monodisperse Magnetite Nanocrystals. J Nanosci Nanotechnol. 2006; 6: 852 -6. https://doi.org/10.1166/jnn.2006.135

14. Sanchez-Delgado AR, Navarro M, Perez H, Urbina JA. Towards a Novel based Chemotherapy against tropical diseases. Synthesis and anti-malarial activity in-vitro and in-vivo of new ruthenium and Rhodium Chloroquine complexes. J Med Chem, 1996; 39: 1095-9.

https://doi.org/10.1021/jm950729w

15. Wright PJ, Leathwood PD, Plummer DT. Enzymes in rat urine. Alkaline phosphatase. Enzymologia 1972, 42: 317-27.

16. Reitman S, Frankel S. Determination of serum transaminases. Am J Clin Pathol. 1975; 28:56-9. https://doi.org/10.1093/ajcp/28.1.56

17. Wroblewski F. La Due JS. Lactate dehydrogenase activity in blood. Proc Soc Exp Biol Med. 1955; 90: 210.

https://doi.org/10.3181/00379727-90-21985

18. Tella AC, Isaac AY, Adeniran RA. Mechanochemical synthesis and characterization of 2, 4-dinitrophenyl hydrazine metal complexes. International Journal of Applied Chemistry. 2011; 7:25-32.

19. Biot C, Dubar F, Khalife J, Slomianny C. Opening up the advantages of the ruthenocenic bioprobes of ferroquine: distribution and localization in Plasmodium falciparum infected erythrocytes. Metallomics. 2012; 4 :780-3. 


\section{https://doi.org/10.1039/c2mt20063e}

20. Carlton JM, Angiuoli SV, Suh BB et al. Genome sequence and comparative analysis of the model rodent malaria parasite. Nature 2002; 419:512-9.

https://doi.org/10.1038/nature01099

21. Malomo SO. Toxicological implication of ceftriaxone administration in rats. Nig J Biochem Mol Biol. 2000; 15: 33-8.

22. Akanji MA. A comparative biochemical study of the interaction of some trypanocides with rat tissue cellular system. Ph.D Thesis, University of Ife, lle-Ife, Nigeria. 1986.

23. Wright PJ and Plummer DT. The use of Urinary enzyme measurement to detect renal damage caused by nephrotoxic compounds. Biochem Pharmcol. 1974;12:65-73.

24. Akanji MA, Olagoke OA, Oloyede OB. Effect of chronic consumption of metabisulphite on the integrity of rat cellular system. Toxicol. 1993; 81: 1739.

https://doi.org/10.1016/0300-483X(93)90010-P

25. Pari L, Amali RD. Protective role of tetrahydrocurcumin (THC) an active principle of tumeric on chloroquine induced hepatoxicity in rats. J Pharm Pharm Sci 2005; 8:115-23.

26. Farombi EO, Olowe BI, Emerole GO. Effect of three structurally related antimalarial drugs on liver microsomal components and lipid peroxidation in rats. Comp Biochem Physiol C Toxiicol Pharmacol. 2000; 126:217-24. https://doi.org/10.1016/S0742-8413(00)00116-X

27. Philip DM. Plasma enzymes in diagnosis. In: Clinical Chemistry in Diagnosis and Treatment. 6th edition. Arnold Publishers, London, Pp. 303-307, 1995.

28. Huang J, Zhou W, Dong $W$ et al. From the Cover: Directed, efficient, and versatile modifications of the Drosophila genome by genomic engineering. Proc Natl Acad Sci USA. 106: 8284--9. https://doi.org/10.1073/pnas.0900641106

29. Morillo CA, Jimoh FO, Odutuga AA. Changes in the activities of some diagnostic enzymes in some rat tissues following the consumption of thermally oxidized groundnut oil. Nig J Biochem Mol Biol. 2001; 16:132S-133S.

30. Ganong WF. Review of Medical Physiology. 9th Edition.Lange Medical Books/McGraw-Hill Medical Publishing Division, London. Pp 543, 1977 


\title{
Mehanohemijska sinteza i procena in vivo antimalarijske efikasnosti i bezbednosti amodiakin-cink kompleksa
}

\author{
Rotimi Olusanya Arise ${ }^{1}$, Sunday-Nwaso Elizabeth ${ }^{1}$, Samuel Tobi Farohunbi ${ }^{1}$, \\ Mikhail Olugbemiro Nafiu ${ }^{1}$, Adedibu Clement Tella ${ }^{2}$ \\ ${ }^{1}$ Departman za biohemiju, Univerzitet Ilorin, Nigerija \\ ${ }^{2}$ Departmane za hemiju, Univerzitet Ilorin, Nigerija
}

\section{SAŽETAK}

Do sada su razvijeni neki od antimalarijskih lekova na bazi metala. U ovoj studiji opisana je mehanohemijska sinteza, karakterizacija kompleksa Zn (II) sa amodiakinom, kao i njegova antimalarijska efikasnost na miševima zaraženim Plasmodium bergheimom i procena njegove bezbednosti.

U studiji je procenjena mehanohemijska sinteza bez upotrebe rastvarača i karakterizacija kompleksa Zn (II) sa amodiakinom, kao i njegova antimalarijska efikasnost na NK-65 miševima inficiranim pomoću Plasmodium berghei.

Derivatizacija amodiakina sa cink (II) jonom povećala je aktivnost leka kroz značajno poboljšanje $(\mathrm{p}<0,05)$ supresije parazitemije kod potvrđene malarije u poređenju sa kontrolnom grupom, dok je njegov kapacitet za čišćenje parazita malarije bio sličan onome kod hlorokv .in aZapaženo je značajno smanjenje aktivnosti alkalne fosfataze, laktat dehidrogenaze, alanina $i$ aspartat aminotransferaza $u$ jetri, bubrezima $i$ tankom crevu, dok su se njihovi nivoi značajno povećali u plazmi. Nivoi PCV, Hb, RBC i limfocita bili su značajno smanjeni $(p<0,05)$, a uočeno je i značajno povećanje $(p<0,05)$ koncentracija leukocita i neutrofila u svim grupama koje su lečene u poređenju sa kontrololnom grupom.

Rezultat ukazuje da je koordinacija cinka (II) sa amodiakinom pomoću mehaničke indukcije poboljšala njegovu antimalarijsku aktivnost, dok su izmene $u$ ispitivanim biohemijskim parametriama ukazivale na funkcionalnu i strukturnu toksičnost. Stoga, kompleks Zn (II) sa amodiakinom ne može biti potpuno bezbedan za produženu i ponovljenu upotrebu kao oralni antimalarijski lek.

Ključne reči: antimalarijski, amodiakine-cink, mehanohemijska sinteza, in vivo i procena bezbednosti 